\title{
O Papa Francisco e uma percepção sobre a Educação
}

Glória Fátima do Nascimento ${ }^{1}$

Em uma audiência, no início de 2017 aos participantes da plenária da Congregação para a Educação Católica, o Papa Francisco citou três chaves que a Educação deve levar em conta: "Humanizar a educação", "cultura do diálogo" e "semear a esperança"

A partir dessas três chaves de leitura, iniciaremos um diálogo com o Papa Francisco. Ressaltamos que é início de diálogo, não é tarefa completa. É exercício de reflexão de uma educadora que percebe na postura de Francisco, em cada atitude, em cada ato deliciosamente desconcertante a postura de um educador, não fosse ele membro da Companhia de Jesus, diria ser estranho..., mas fico com as palavras dos jovens, creio que ele é "sinistro", "do bem", profeta da paz.

\section{Como humanizar a educação?}

O reconhecimento da liberdade infinita do outro, do seu direito de humanizar seu mundo e a si mesmo é que fundamenta a perspectiva de uma Educação Cristã. Quando o rosto do outro se revela como exterior, como liberdade que interpela e que provoca; como resistência à totalização instrumental, é que ele aparece como outro, como pessoa.

Então, a alteridade é vivenciada como experiência pessoal e coletiva. O outro me provoca, chama (voca) de frente (pro), na medida que me é exterior.

A Educação fundamentada nos conceitos apresentados por Francisco vai fornecer princípios para irromper uma nova prática, substituindo o cientificismo pelo encaminhamento de uma prática educativa que articule bem técnica - ética - política. Onde se conjugue eficiência técnica com consciência ética.

É no encontro com o outro (alteridade) que experimento quem é Deus. A experiência é uma modalidade de conhecimento que se dá pela percepção simples e imediata do objeto; nesta, está implicado o ser humano todo (com seu conhecimento, vontades e sentimentos). Para a tradição cristã o coração é o locus onde tal apreensão se dá. O coração simboliza o mais profundo do ser humano.

O Papa nos leva a refletir: estamos conduzindo (educando - ex-ducere $=$ conduzir para fora) nossos alunos a serem construtores de uma sociedade mais justa? Estamos formando pessoas que são próximas ao outro? Que realmente sabem dialogar?

\section{Cultura de diálogo... o que será?}

A palavra cultura é polissêmica, portanto, precisamos deixar claro de que visão partimos. Hoje em dia, aliás, fala-se em culturas, é uma palavra plural.

${ }^{1}$ Diretora do Colégio Teresiano CAP-PUC, professora do Departamento de Teologia, setor Cultura Religiosa, teóloga e pedagoga. 
Para o antropólogo C. Geertz, a cultura é uma teia de significados tecida pelo ser humano. Tal teia orienta a existência humana; trata-se de um sistema de símbolos que interage com os sistemas de símbolos de cada indivíduo numa interação recíproca.

A cada cultura, a cada grupo cultural correspondem línguas, normatizações e jogos simbólicos próprios. $A(s)$ cultura(s) são as lentes com as quais vemos o mundo.

Etimologicamente, diálogo significa, dia = por intermédio de + logo = palavra, ou seja, por intermédio da palavra: ouvir, trocar e somar ideias, sentimentos, sensações, saberes e tudo aquilo que nos faz caminhar até ao outro, ao diferente de nós mesmos.

Portanto, uma "cultura de diálogo" significa buscar uma real aproximação do outro. Estar próximo ao outro, percebê-lo em sua exterioridade. Neste aspecto a proposta de Jesus Cristo é audaciosa pois nos convida a amar o diferente. E esta é uma possibilidade desenvolvida naqueles que têm sede da própria liberdade; os que buscam na libertação do outro, a própria felicidade.

A libertação é um conceito muito concreto que se caracteriza por ser profundamente hebreu. No Êxodo, Deus diz a Moisés: "Liberta-os", isto é, faz com que deixem o Egito, salva-os. O ethos adâmico convida a pessoa a colocar-se na luta pela libertação, eticamente. Clama que se perceba o bem ético como justiça, criando uma consciência ética ouvindo a voz do outro, não repetindo o habitual, o mesmo, mas criando atitudes novas, que tenham como Orientação Fundamental a libertação do outro. Desse modo, antecipando-se agora a grande libertação que é o Reino de Deus.

Portanto, liberdade é um conceito que perpassa pela alteridade. Como são percebidos, evidenciados os conceitos de liberdade, alteridade, experiência, atos livres, orientação fundamental (que poderiam levar a maturidade e a responsabilidade) no campo da educação? Educar para a liberdade, construir uma sociedade justa, solidária, participativa é anunciar o Reino de Deus. É caminhar para a maturidade, crescer como pessoa, como cidadão maduro e solidário, sensíveis ao projeto apresentado por Jesus Cristo ao mundo.

A Educação Cristã percebe que a revelação de um Deus pessoal ajuda o ser humano a se auto reconhecer como pessoa, sujeito da própria história e responsável pela história do outro/a.

\section{Por uma Pedagogia da Esperança}

Como semear a esperança, através da educação?

Neste sentido recorremos a Paulo Freire. Segundo Freire, a educação é uma prática política tanto quanto qualquer prática política é pedagógica. Assim sendo, os educadores necessitam construir conhecimentos com seus alunos tendo como horizonte um projeto coletivo de sociedade. Os educadores são profissionais da pedagogia da esperança. 
Em seus trabalhos, Freire defende a ideia de que a educação não pode ser um depósito de informações do professor sobre o aluno. Esta "pedagogia bancária", segundo Freire, não leva em consideração os conhecimentos e a cultura dos educandos.

Respeitando-se a linguagem, a cultura e a história de vida dos alunos pode-se levá-los a tomar consciência da realidade que os cerca, discutindo-a criticamente. Deste modo os conteúdos jamais poderão ser desvinculados da vida.

A base da pedagogia de Paulo Freire é o diálogo libertador. Na relação dialógica estabelecida entre o educador e o educando faz-se com que este aprenda a aprender. Paulo Freire afirma que a "leitura do mundo precede a leitura da palavra", com isto querendo dizer que a realidade vivida é a base para qualquer construção de conhecimento. Respeita-se o educando não o excluindo da sua cultura, fazendo-o de mero depositário da cultura dominante.

Ao se descobrir como produtor de cultura, os seres humanos se veem como sujeitos e não como objetos da relação ensino/aprendizagem.

A educação, segundo Freire, deve ter como objetivo maior desvelar as relações opressivas vividas pelas pessoas, transformando-as para que elas transformem o mundo. Mais do que ler, escrever e contar, a escola tem tarefas mais sérias - desvelar para todos as contradições da sociedade em que vivem.

\section{Conclusão}

O Papa Francisco em sua homilia na Celebração das Vésperas com a participação dos universitários em Roma (30/11/13) nos diz: "Vós sabeis, queridos jovens universitários, que não se pode viver sem olhar os desafios. (...). Por favor, não olheis a vida da varanda! Misturai-vos lá, onde estão os desafios!"

Anteriormente, no discurso aos estudantes e professores de um Colégio Japonês em viagem a Roma (21/08/13) nos exorta:

E qual é atitude mais profunda que devemos ter para dialogar? A mansidão, a capacidade de encontrar as pessoas, de encontrar as culturas com a paz; a capacidade de fazer perguntas inteligentes: 'mas por que pensas assim? Por que esta cultura é assim?'. Ouvir o próximo e depois falar. Primeiro ouvir, depois falar. Tudo isto é mansidão. Se tu não pensas como eu - sabes... penso de outro modo, não me convences - mas somos amigos à mesma; ouvi como tu pensas e tu me ouviste como eu penso.

\section{Dois convites fecundos:}

- Não olhar a vida da varanda! Ir ao encontro dos desafios!

- Dialogar, escutar, refletir junto ao diferente. 


\section{Algumas questões:}

1 - Como você definiria sua identidade cultural?

2 - Em que momentos cada um de nós é chamado a dialogar com o diferente (pense nas relações entre diferentes continentes, nas relações homem/mulher, adulto/criança, professor/aluno, pais/filho...)

3 - Atreva-se a conjugar o verbo esperançar.

Um desafio: escreva uma carta a um amigo/a e explique para ele/ela o que é "esperançar".

Segundo o filósofo brasileiro Mario Sergio Cortella:

"Como insistia o inesquecível Paulo Freire, não se pode confundir esperança do verbo esperançar com esperança do verbo esperar. Aliás, uma das coisas mais perniciosas que temos nesse momento é o apodrecimento da esperança; em várias situações as pessoas acham que não tem mais jeito, que não tem alternativa, que a vida é assim mesmo... Violência? o que posso fazer? Espero que termine... Desemprego? O que posso fazer? Espero que resolvam... Fome? O que posso fazer? Espero que impeçam... Corrupção? O que posso fazer? Espero que liquidem... Isso não é esperança, é espera. Esperançar é se levantar, esperançar é ir atrás, esperançar é construir, esperançar é não desistir! Esperançar é levar adiante, esperançar é juntar-se com outros para fazer de outro modo. E, se há algo que Paulo Freire fez o tempo todo, foi incendiar a nossa urgência de esperanças"

\section{Bibliografia}

CUNHA, A. G. Dicionário Etimológico Nova Fronteira. Rio de Janeiro: Nova Fronteira, 1982.

DUSSEL, E.. Ética da Libertação, na Idade da Globalização e da Exclusão. Petrópolis: Vozes, 2000.

FREIRE, Paulo. Pedagogia da esperança: um reencontro com a Pedagogia do oprimido. São Paulo: Paz e Terra, 2013.

GEERTZ, c. A Interpretação das Culturas. Rio de Janeiro:LTC, 2017.

NASCIMENTO, Glória Fátima. Dissertação de Mestrado: Teologia, Educação e Escola

Católica, um diálogo necessário. PUC-Rio, 2003. 